\title{
P2X7Rs: new therapeutic targets for osteoporosis
}

\author{
Haoyun Huang ${ }^{1} \cdot$ Yu-Mei He ${ }^{2} \cdot$ Miao-Miao Lin $^{2} \cdot$ Yanchao Wang ${ }^{3} \cdot$ Xiaomei Zhang $^{4} \cdot$ Li Liang $^{5} \cdot$ Xueling He $^{4}(\mathbb{D}$
}

Received: 21 October 2021 / Accepted: 17 December 2021 / Published online: 2 February 2022

(c) The Author(s) 2022

\begin{abstract}
Increasing evidence suggests that both the occurrence and progression of osteoporosis are associated with inflammation, especially in primary osteoporosis. The maintenance of skeletal homeostasis is dependent on the complex regulation of bone metabolism. Numerous evidence suggested that purinoceptor networks are essential for bone homeostasis. In this review, the relationship between inflammation and the development of osteoporosis and the role of $\mathrm{P} 2 \mathrm{X} 7$ receptor (P2X7R) in regulating the dynamic regulation of bone reconstruction were covered. We also discussed how P2X7R regulates the balance between resorption and bone formation by osteoblasts and reviewed the relevance of P2X7R polymorphisms in skeletal physiology. Finally, we analyzed potential targets of P2X7R for osteoporosis.
\end{abstract}

Keywords Inflammation $\cdot$ Osteoporosis $\cdot \mathrm{P} 2 \mathrm{X} 7$ receptor $\cdot$ Osteoclasts $\cdot$ Osteoblasts

Haoyun Huang is an undergraduate student of Chengdu university of traditional Chinese medicine. His research interest is focusing on the purinergic signaling and bone metabolism diseases.

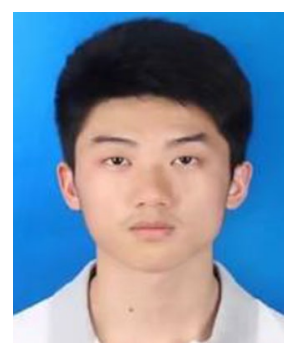

Haoyun Huang, Yu-Mei He and Miao-Miao Lin contibuted equally to this work

Xueling He

hxlscu@163.com

Haoyun Huang

1813137986@qq.com

Yu-Mei He

yumeiar@126.com

Miao-Miao Lin

lin_miaomiao97@sina.com

Yanchao Wang

wangyanchao@scu.ecu.cn

Xiaomei Zhang

623834392@qq.com

Li Liang

lilianghx@163.com
1 Clinical Medical School, Chengdu University of Traditional Chinese Medicine, Chengdu 610072, China

2 School of Sports Medicine and Health, Chengdu Sports University, Chengdu 610041, China

3 Department of Neurosurgery, West China Hospital, Sichuan University, Chengdu 610041, China

4 Laboratory Animal Center of Sichuan University, Chengdu 610041, China

5 Institute of Biomedical Engineering, West China School of Basic Medical Sciences and Forensic Medicine, Sichuan University, Chengdu 610041, China 


$\begin{array}{ll}\text { Abbreviations } \\ \text { ATP } & \text { Adenosine triphosphate } \\ \text { P2X7R } & \text { P2X7 receptor } \\ \text { PMOP } & \text { Postmenopausal osteoporosis } \\ \text { HSCs } & \text { Hematopoietic stem cells } \\ \text { BMSCs } & \text { Bone marrow mesenchymal stem cells } \\ \text { RANKL } & \begin{array}{l}\text { Nuclear transcription factor- } \kappa \text { B receptor activa- } \\ \text { tor ligand }\end{array} \\ \text { IFN- } \alpha 2 & \text { Interferon alpha 2 } \\ \text { ERK } & \text { Extracellular signal-regulated kinase } \\ \text { PKC } & \text { Protein kinase C } \\ \text { NFATc1 } & \text { Nuclear factor of activated T cells 1 } \\ \text { TNF- } \alpha & \text { Tumor necrosis factor- } \alpha \\ \text { ALP } & \text { Alkaline phosphatase activity } \\ \text { SNPs } & \text { Single-nucleotide polymorphisms }\end{array}$

\section{Introduction}

Bone mass is gradually lost with age, leading to osteoporosis, which is a systemic skeletal disorder characterized by reduced bone mass, increased bone fragility, and fracture risk due to the destruction of bone microstructures [1]. It is estimated that $25 \%$ women over 50 years and $20 \%$ men over 50 years suffer from osteoporosis. Fractures caused by age-related bone loss are the main cause of disability and death in elderly patients, seriously affecting the lives of the elderly, and bringing a heavy economic burden to patients and society $[2,3]$. With the aging of the global population, aging-related osteoporosis has grown up to be a public health problem worldwide.

Osteoporosis is divided into primary osteoporosis (such as postmenopausal osteoporosis and senile osteoporosis) and secondary osteoporosis(such as disease processes. It is now believed that the decline in estrogen levels and bone degenerative changes are the main causes of osteoporosis, but osteoporosis is a complex multi-factor disease involving genetic and environmental factors [4]. In recent years, clinical studies have found that many inflammatory diseases are commonly accompanied by obvious local or systemic bone loss, such as glucocorticoids [5], rheumatoid arthritis [6], diabetes [7], kidney disease [8], cardiovascular disease [9], and so on. These findings suggest that inflammation is closely linked to osteoporosis. With more studies carried out on animals and humans, the evidence that inflammation plays an important role in the occurrence and progression of postmenopausal osteoporosis and age-related osteoporosis is becoming clearer.

In recent years, the role of adenosine triphosphate (ATP) and its associated receptors in the inflammatory process has been identified. ATP is a natural ligand for the P2X receptor (the metabotropic receptor family) and its expression on all osteoblast types (osteoclasts, osteoblasts, and osteocytes) has been demonstrated [10]. There is growing evidence suggesting that purinergic signaling also plays a critical role in the physiological regulation of bone metabolism [11-13]. Although several reviews on the role of $\mathrm{P} 2 \mathrm{X}$ receptors in bone biology have been reported, the majority of studies were focused on P2X7R. Activation of P2X7R may ameliorate osteoporosis by regulating the balance between osteoblasts and osteoclasts, and the balance between resorption and bone formation by osteoblasts remains essential for skeletal homeostasis $[14,15]$. Therefore, P2X7R has great potential therapeutic targets for inflammatory osteoporosis. In this paper, we systematically reviewed the role of P2X7R in the dynamic regulation of bone reconstruction and its targeting potential.

\section{Relationship between inflammation and osteoporosis}

\section{Inflammation and the postmenopausal osteoporosis}

Decreased ovarian function and decreased estrogen levels in postmenopausal women are the main reasons for rapid bone loss leading to osteoporosis [16]. However, numerous studies have demonstrated that the decline of postmenopausal estrogen levels can increase the inflammatory cytokines [17-19]. Early research has shown that serum inflammatory indexes and P2X7R [20,21] are significantly higher in women with postmenopausal osteoporosis (PMOP). The $\mathrm{T}$ cell activity and nuclear transcription factor- $\mathrm{\kappa B}$ receptor activator ligand (RANKL) expression increased, as well as the various inflammatory cytokines released by $\mathrm{T}$ cells that promote bone resorption. However, the levels of these inflammatory cytokines reduced significantly when given estrogen replacement therapy [22]. In addition, early clinical research has aslo found that the interleukin-1 (IL-1) and tumor necrosis factor- $\alpha$ (TNF- $\alpha$ ) levels in serum were significantly increased in women who had undergone surgical removal of the ovaries, and reduced to preoperative levels after 4 weeks of estrogen replacement therapy [23]. Similar research results were also found in animal studies. The number of thymus, $\mathrm{T}$ cells, and the TNF- $\alpha$ released by $\mathrm{T}$ cells were significantly increased in ovariectomized mice or rats, and the bone mass can be close to the pre-ovariectomized level after administration of IL-1 receptor antagonist and TNF-binding protein, and the therapeutic effect is similar to estrogen replacement treatment [24-26]. Further research found that the bone loss of ovariectomized $\mathrm{TNF}^{-/}$mice was considerably less than that of wild-type mice. At the molecular level, TNF- $\alpha$ and IL- $1 \beta$ are considered to be effective inflammatory signals, as well as regulators of osteoclast formation and activity, which may be partly responsible for 
the rapid premenopausal bone loss [27, 28]. These studies suggested that inflammatory cytokines are essential in the occurrence and development of women with PMOP.

\section{Inflamma-aging and the senile osteoporosis}

Inflamma-aging is a progressive chronic pro-inflammatory state that appears with aging [29]. It plays key roles in many senile diseases, such as Alzheimer, Parkinson, multiple sclerosis, atherosclerosis, diabetes, osteoporosis, and so on [30, 31]. The mechanisms of inflammatory aging are associated with inflammatory cytokines, autophagy, oxidative stress, and DNA damage [32].

Studies have shown that aging is a key driver of bone loss and bone fragility. The bone loss that occurs with aging reflects the confluence of various molecular and cellular processes. Therefore, similar to the mechanism of PMOP, inflammation also plays an important part in senile osteoporosis. The expression levels of inflammatory cytokines such as TNF- $\alpha$, IL-1, IL-6, and IL-17, which are serum markers of inflammatory-aging, increased with age [33]. Moreover, the increased levels of these inflammatory cytokines produce a large number of osteoclasts and inhibit the activity of osteoblasts [34]. Macrophage colony stimulating factor (M-CSF), which plays an important role in the survival and proliferation of osteoclasts, is an important cytokine during the differentiation of osteoclast precursor cells into mature osteoclasts. TNF- $\alpha$ can promote the production of M-CSF in a direct or indirect manner. In addition, TNF- $\alpha$ can also inhibit the production of osteoblasts, reduce bone matrix calcification, and ultimately lead to an imbalance of bone formation and bone resorption. IL-1 is another important cytokine that affects bone metabolism and bone remodeling activities in the bone microenvironment. It can stimulate osteoclast production and produce a strong effect on bone resorption. Similarly, increased levels of IL-6 can also lead to increasing levels of TNF- $\alpha$ and IL-1. These inflammatory cytokines promote bone resorption by enhancing the activation and differentiation of osteoclasts, and inhibiting the survival of osteoblasts.

Autophagy is the self-protection mechanism of cells, which plays an important role in the maintenance of cellular homeostasis, proliferation, differentiation, and stress. The autophagy level of bone cells gradually decreased with aging, which increased the secretion of pro-inflammatory cytokines, accelerated bone loss, and then leaded to osteoporosis [35]. The ability of cells to be eliminated through autophagy was reduced, and mitochondrial dysfunction leaded to protein accumulation with aging [36]. As a result, oxidative stress and ROS increase, and inflammation occurs, which further lead to increased inflammation and accelerated aging [37].

A recent study found that changes in aging skeletal stem cells (SSC) may be one of the key factors leading to poor fracture healing, osteoporosis, and various blood diseases [38, 39]. Aged bone stem cells have lower activity and poorer ability to form bones. Further research found that the genes expressed by aged bone stem cells are mainly related to decreased bone formation and enhanced bone resorption. Aged skeletal stem cells affected not only the lower ability to form bones, but also the growth of hematopoietic stem/progenitor cells (HSPC), leading to more bone-absorbing cells and producing inflammatory cytokines that cause fibrous tissue instead of bone growth. This imbalance between bone formation and bone resorption ultimately leads to osteoporosis [40].

However, there are still few studies on the related mechanisms of inflamma-aging and osteoporosis. We believe that there will be more studies in the future to explore the impact of the relationship between them on bone metabolism.

\section{P2X7 receptor and ATP-mediated purinergic signaling during inflammation}

ATP exists in all cells and has been identified as an extracellular signaling molecule, which is involved in several signal pathways in various kinds of cells and diseases. ATP is mainly released by immune cells and hematopoietic cells as well as osteoblasts and osteocytes $[8,26$,$] .$ Compared with cytoplasm, the normal ATP concentration is relatively low in the extracellular, but the extracellular concentration of ATP is usually increased in damaged tissue, tumor, inflammation, or fracture [37, 41]. P2X7R, one of the seven receptor subtypes, plays a key role in mediating the activation of NLRP3 inflammasomes. The non-selective ligand cation channel formed by the activated P2X7R causes lots of $\mathrm{Ca}^{2+}$ and $\mathrm{Na}^{+}$influx and changes the membrane potential and leads to the efflux of $\mathrm{K}^{+}$through the TWIK2 (the Kcnk6 gene code) channel. TWIK2 and P2X7R synergistically activate NLRP3 inflammasomes. Activated NLRP3 inflammasomes mediate the activation of caspase- 1 to mature the precursor IL- $1 \beta$ and induce the release of mature IL- $1 \beta$ to the cytoplasm. In addition, a large amount of $\mathrm{Ca}^{2+}$ influx caused by activated P2X7R can activate calmodulin-dependent protein kinase II and $\mathrm{Ca} 2+-$-dependent phospholipase $\mathrm{A} 2$, and induce the release of IL- $1 \beta[28,42]$. P2X7R can also promote the production of reactive oxygen species (ROS) by macrophages, which is involved in the activation of the p38 and JNK pathways mediated by the nucleotide receptor. However, the activated ROS, p38, and JNK pathways all together play a critical role in a variety of immune response processes [43]. It can be seen that ATP-P2X7R signaling plays an important role in the inflammatory process caused by macrophages.

Beyond these, P2X7R is also involved in the activation and expression of transcription factors, such as nuclear 
factor- $\kappa \mathrm{B}(\mathrm{NF}-\kappa \mathrm{B})$. NF- $\kappa \mathrm{B}$ is a nuclear transcription factor that controls the expression of a variety of inflammatory genes, including TNF- $\alpha$, COX- 2 , and IL- $1 b$, increased TNF- $\alpha$ and IL- $1 \beta$ can enhance NF- $\kappa B$ activation and further exacerbate inflammation in turn. An increasing number of studies link the pro-inflammatory activity of P2X7R to NF-KB nuclear translocation, further confirming the P2X7R-dependent activation of NF-KB in microglia, osteoclasts, and osteoblasts [28, 42].

\section{Dynamic regulation of $\mathrm{P} 2 \mathrm{X7R}$ on bone remodeling}

$\mathrm{P} 2 \mathrm{X} 7 \mathrm{R}$, as a ligand ion gating system, is widely distributed in osteocytes, osteoclasts, and osteoblasts, which plays an important role in bone remodelling. Moreover, as a repair receptor, P2X7R can promote the repair and calcification of small fractures, thereby accelerating bone remodeling [44]. A proper balance between osteoclasts and osteoblasts is essential for healthy bones [45]. P2X7R may ameliorate osteoporosis by maintaining a balance between osteoclast and osteoblast activity [46-48].

\section{The effect of ATP and P2X7R on osteoclasts}

\section{Osteoclast precursor cells}

Osteoclasts, the bone-resorbing cells, are generated from mononuclear monocyte-macrophage precursors that derived from hematopoietic stem cells (HSCs) in the bone marrow. Cells of HSCs lines have also been demonstrated to express multiple purine receptors [49, 50]. Extracellular ATP can promote the transformation of HSCs to myeloid progenitor/ osteoclast precursor cells. Studies have shown that a high concentration of ATP $(1 \mathrm{mM})$ can reduce the number of HSCs in mice, while increased in bone marrow cells. HSCs have not changed significantly when exposed to low concentrations of ATP (less than $1 \mathrm{mM}$ ) [51]. These indicated that the role of $\mathrm{P} 2 \mathrm{X} 7 \mathrm{R}$ in promoting HSCs may be along the osteoclast cell line.

Osteoclasts are large multinucleated terminally differentiated cells formed by the fusion of mononuclear hematopoietic precursors, but the fusion of precursor cells to multinucleated osteoblasts is a complex biological behavior that is not yet completely understood. Recently, it has been shown that osteoclast precursor fusion to form multinucleated cells was significantly inhibited by anti-P2X7R antibodies or antagonists of oxidized ATP, for example, human blood monocyte formation of osteoclast-like cells can be prevented by some P2X7R antagonists in vitro [52, 53]. ATP can also act on P2X7R promoting the fusion and the differentiation of osteoclast precursors, as well as cell apoptosis through downstream signaling pathway, such as PKC translocation, nuclear localization of NF- $\mathrm{\kappa B}$, and activation of nuclear factor of activated T cells 1 (NFATc1) [54]. Beside that, extensive internalization of P2X7R induced by prolonged exposure to ATP can also block the ability of RAW 264.7 cells to fuse into multinucleated osteoclast-like cells [55].

\section{Mature osteoclasts}

P2X7R is expressed in osteoclasts generated from rodents and rabbits in vitro, and differentiation of primary mouse osteoclasts is dependent on P2X7R expression [56, 57]. $\mathrm{P} 2 \mathrm{X} 7 \mathrm{R}$ expression is also present in human monocyte precursors and throughout osteoclastogenesis in vitro, and the expression of mRNA and protein of P2X7R was higher in mature resorbing cells compared to their precursors [53, 58]. Highly expressed R2X7 promotes spontaneous fusion of osteoclasts in vitro. Subsequent studies verified that the addition and accumulation of ATP promoted osteoclast fusion [59]. Therefore, we hypothesized that osteoclast fusion requires the release of ATP through the P2X7R pore, although this action may indirectly involve other purinergic receptors. Interestingly, similar to the HSCs, the ATP-mediated P2X7R also has multiple effects on osteoclasts. ATP could enhance osteoclast formation and resorption when it is at a low concentration $(0.2-2 \mu \mathrm{M})$. However, higher concentrations (20-200 $\mu \mathrm{M})$ of ATP may have an adverse effect on osteoblasts, such as the formation of lytic pores that leads to apoptosis and persistent inflammation [60]. It has been noted that bone resorption was decreased by extracellular ATP, which was likely resulted from cytotoxic effect by activated P2X7R on osteoclasts [61]. In summary, activation of P2X7R in osteoclasts is essential for cell fusion and is critical in determining cell survival time and uptake. It can be hypothesized that the formation of osteoclasts and their P2X7R functions are regulated by regulating the extracellular ATP concentration.

\section{The effect of ATP and P2X7R on osteoblasts}

\section{Osteogenic precursors cells}

Osteoblasts are derived from bone marrow mesenchymal stem cells (BMSCs) and various purinergic receptors which plays an important role in determining the differentiation fate of MSCs. Intracellular ATP releases activate P2X7R and drive osteogenic differentiation of MSCs [62, 63]. That shock wave induces osteogenic differentiation of human MSCs through ATP release and activation of P2X7R had just demonstrated. The researchers found that 
shock waves caused ATP to be released from hMSCs and led to downstream activation of the 38 MAPK signaling pathway, transcription of c-Fos and c-Jun mRNAs, and osteogenic differentiation [64]. These downstream events were completely abolished when treated with apyrase (an enzyme that hydrolyzes extracellular ATP), P2X7RsiRNA, PPADS (a nonselective P2 antagonist), and KN-62 (a P2X7R antagonist), which suggests P2X7R-mediated these events [64].

In another study, P2X7R was shown to induce zeiosis to promote osteogenic differentiation and mineralization of BMSCs in postmenopausal women [65]. The authors found that BzATP $(100 \mu \mathrm{M})$ induced the activation of protein kinase $\mathrm{C}$ (PKC) and Rho-related kinase, as well as cytoskeletal rearrangement in BMSCs. Basal alkaline phosphatase activity (ALP) of BMSCs was significantly delayed in postmenopausal women compared to younger women, and the results suggest that the osteogenic capacity of aging BMSCs in postmenopausal women is impaired, and this can be reversed by BzATP. Activation of P2X7R by BzATP enhanced ALP activity, expression of transcription factors RUNX2 and osterix, mineralized area, and number of bone nodules in BMSCs. Collectively, these findings provided important information to disclose the role of $\mathrm{P} 2 \mathrm{X7 \textrm {R }}$ in promoting the differentiation of MSCs into mature osteoblasts.

\section{Mature osteoblasts}

P2X7R has now been verified to be expressed in human and rodent osteoblast cell lines, such as osteoblast-like cell lines, calcareous, and bone-derived primary osteoblasts, whether it has a physiological function in osteoblasts has been controversial $[46,66,67]$. It was observed that $\mathrm{P} 2 \mathrm{X} 7 \mathrm{R}$ knockdown (KO) reduced ALP activity in osteoblasts in vitro, decreased periosteal formation in long bones of P2X7R KO mice and their osteogenic capacity under mechanical loading, and these results were similarly confirmed in human osteoblasts [68, 69]. Furthermore, the marked enhancement of mineralization in human osteosarcoma cell lines when P2X7RB (a truncated P2X7R isoform) was co-expressed with the full variant P2X7RA, suggests a positive role of fully functional P2X7R in maintaining bone strength [70]. Clearly, functional P2X7R is required during osteogenesis. However, the results of some other similar studies are contrary. Activated P2X7R induced apoptosis in SaOS-2 osteoblast cell line, induced membrane blebbing in mouse calvarial osteoblasts and MC3T3-E1 osteoblasts as well as decreased bone mineralization and ALP in primary rat osteoblasts [71-73]. Interestingly, blockade or deletion of P2X7R inhibited the propagation of intercellular calcium signals between osteoblasts and osteoclasts in human bone marrow-derived cells, and fluid shear stress caused a significant reduction in extracellular signal-regulated kinase (ERK) phosphorylation in primary mouse osteoblasts [56, 74]. It is clear that conflicting evidence for the effects of activated P2X7R on osteoblast differentiation and matrix mineralization in vitro indicated that the underlying mechanisms are not clear. Researchers attributed these differences in part to $\mathrm{P} 2$ receptor-dependent and/or receptor-independent mechanisms via hydrolysis of extracellular nucleotides to pyrophosphate (PPi), which is known as a mineralization inhibitor. The breakdown of ATP by ectonucleotidases can cause high-level PPi $[69,75]$.

In general, constitutive ATP in osteoblasts is released at a low level (approximately $0.5-1 \mathrm{nmol} / \mathrm{mL}$ ) in a normal physiological environment [76]. ATP release triggered by mechanical stimulation enhances P2X7R-mediated osteogenic function, and agonist-mediated transient activation of $\mathrm{P} 2 \mathrm{X} 7 \mathrm{R}$ promotes osteoblast differentiation and matrix mineralization [77, 78]. Activation of $\mathrm{P} 2 \mathrm{X} 7 \mathrm{R}$ is involved in downstream LPA synthesis/release, PGE2 synthesis/release, and ERK1/2 activation in osteoblasts, thereby enhancing osteoblast differentiation and bone formation [38, 63, 67]. Yet, high concentrations of ATP(above $1 \mathrm{mM}$ )partially inhibit bone formation, especially mineralization [79]. Such high concentrations of ATP may only occur with cellular damage (including bone tissue microdamage) or macroscopic fractures in vivo [28]. Thus, activation of P2X7R by ATP in bone may be a warning of danger in tissue or cellular damage.

\section{Osteocytes}

Osteocytes, the mechanosensors of bone and the primary regulator of bone homeostasis, are terminally differentiated osteoblasts. In the adult skeleton, the proportion of osteocytes reaches $90-95 \%$, approximately 20 times that of osteoblasts. Unlike osteoblasts and osteoclasts, which are located on the bone surface, osteocytes grow in the bone matrix inside the bone, making it difficult to study them [80]. Despite this, the expression and function of P2X7R in 13 have caught attention. Evidence suggests that BzATP and liquid shear stress can induce MLO-Y4 osteocytes pore formation via $\mathrm{P} 2 \mathrm{X} 7 \mathrm{R}$ and lead to the release of PGE2, which is normally involved in the activation of downstream signals for mechanically induced bone formation [81-83]. However, conflicting evidence indicates that shear stress can also induce the release of PGE2 from MLO-Y4 osteocytes when P2X7R was inhibited [84]. It has been shown that P2X7R is important for the normal anabolic response to physical stimulation of the skeleton, as mechanical stimulation causes the release of large amounts of ATP from osteocytes, and therefore it can be hypothesized that activated P2X7R has a key role in regulating the mechanical load of osteocytes [81]. However, how it is involved in the mechanotransduction cascade of osteocytes remains unclear. 


\section{P2X7R as the link between the immune system and osteoporosis}

\section{P2X7R and chronic inflammatory osteoporosis}

Both autoimmune and other chronic inflammatory diseases are often complicated by osteoporosis and share similar mechanisms. As mentioned previously, P2X7R is a key factor in the inflammatory and many P2X7R-coupled pathways are critical in both the inflammatory response and the regulation of bone metabolism.

The release of large amounts of ATP during inflammation can activate P2X7R on immune cells and the activated P2X7R further further promotes the release of inflammatory cytokines, such as IL- 6 from mast cells, TNF- $\alpha$ from dendritic cells, and PGE2 from macrophages, ultimately maintaining and exacerbating the inflammatory $[85,86]$. Persistent inflammation promotes the release of multiple cytokines such as RANKL, IL-1, IL-6, and TNF- $\alpha$ from immune cells. Activated P2X7R also leads to intracellular $\mathrm{K}^{+}$efflux and Pannexin-1 activation, which accelerates the assembly of NLRP3 inflammasome [87, 88]. Inflammation activates caspase- 1 precursors to active IL- $1 \beta$ by producing IL- $1 \beta$ converting enzyme. IL- $1 \beta$ inhibits osteoblast bone formation by activating the NF-kB signaling pathway, and also promotes osteoclast bone resorption by synergistic effects with TNF- $\alpha$. In addition, TNF- $\alpha$ affects the regulation of intracellular $\mathrm{Ca}^{2+}$ by stimulating Akt signaling to upregulate $\mathrm{P} 2$ receptors, which promotes osteoclast differentiation and enhances bone resorption and accelerates the osteoporosis process [16]. Moreover, as part of the inflammatory process, the release of ATP can locally activate osteoclasts because the immune system and bone are in close contact with the bone marrow. Here, activation of P2X7R in osteoclasts can directly activate osteoclast precursors to form mature multinucleate bone resorbing osteoclasts or indirectly activate osteoclasts by stimulating P2X7R in osteoblasts and upregulating osteoblast RANKL, thereby inducing osteoclast formation [28]. However, besides the cytokines that trigger osteoclast activation (IL-1, IL-6 and TNF- $\alpha$ ) in inflammation, cytokines that inhibit osteoclast differentiation, such as IL-12, IL-18, IL-33 and interferon alpha 2 (IFN- $\alpha 2$ ), are also present, which can inhibit bone loss [46, 89]. Thus, the composition of cytokines in inflammation is decisive for whether inflammation triggers bone loss. Moreover, the skeletal effects of the disease are further exacerbated by reduced activation of P2X7R in osteoblasts due to reduced mobility in patients with primary inflammatory disease (shown in Fig. 1).

In summary, P2X7R activation leads to upregulation of osteoclast bone resorption and downregulation of osteogenesis in osteoblasts, ultimately leading to osteolysis, which may be an important cause of osteoporosis during inflammation and appears to be influenced by high or low ATP levels.

\section{P2X7R and osteoporosis mediated by immune system}

Immunodeficiency diseases are caused by deficiencies in immune function due to underdevelopment or acquired damage to the immune system and are classified as primary or secondary [90]. The mechanism by which it causes osteoporosis is similar to that of inflammation-mediated osteoporosis, due to the sustained activation of P2X7R and osteoclast to inhibit bone formation [91]. B cells, as the sole producers of OPG, play crucial roles in the homeostasis and regulation of bone mass. OPG can be produced by co-stimulation of CD40 on the surface of B cells and CD40L on the surface of $\mathrm{T}$ cells [86]. In autoimmune defects, a large number of $\mathrm{CD} 4+$ cells are functionally impaired and reduced in number, leading to a diminished effect of this co-stimulation, resulting in reduced OPG production, increased RANKL to OPG ratio, osteoclast activation, and accelerated bone loss, increasing the potential for osteoporosis [92].

\section{P2X7R gene polymorphism and osteoporosis}

The gene encoding P2X7R is located on chromosome 12q24 and is highly polymorphic. More than 1500 single-nucleotide polymorphisms (SNPs) are reported in the NCBI SNP database [93, 94]. Multiple single-nucleotide polymorphisms in this gene have been demonstrated to affect the function of this receptor. Studies have shown a distinct association between SNPs in the gene encoding the P2X7R and the development of osteoporosis and fracture risk [95]. Studies have shown a noticeable association between SNPs in the gene encoding the $\mathrm{P} 2 \mathrm{X} 7$ receptor and the development of osteoporosis and fracture risk $[40,96]$. Loss-of-function polymorphisms in the P2X7 receptor gene may increase the risk of osteoporosis in postmenopausal women, and in a group of Dutch fracture patients, $\mathrm{P} 2 \mathrm{X} 7$ receptor polymorphisms were associated with bone mineral density and risk of osteoporosis [97-99]. Genetic abnormalities in P2X7R function lead to reducing BMD and increased risk of osteoporosis [80]. Rs3751143 is widely regarded as associated with the incidence of osteoporosis [92]. It has been reported to be associated with impaired ATP-mediated pore-forming activity, with dominant pure heterozygotes having the strongest pore-forming activity, heterozygotes having the lowest pore-forming activity, and recessive pure heterozygotes losing this function altogether. Rs3751143 impairs the opening of ATP-induced cation-selective channels. Based on studies, RS3751143-C is significantly associated with the development of osteoporosis because carriers carrying the $\mathrm{C}$ 


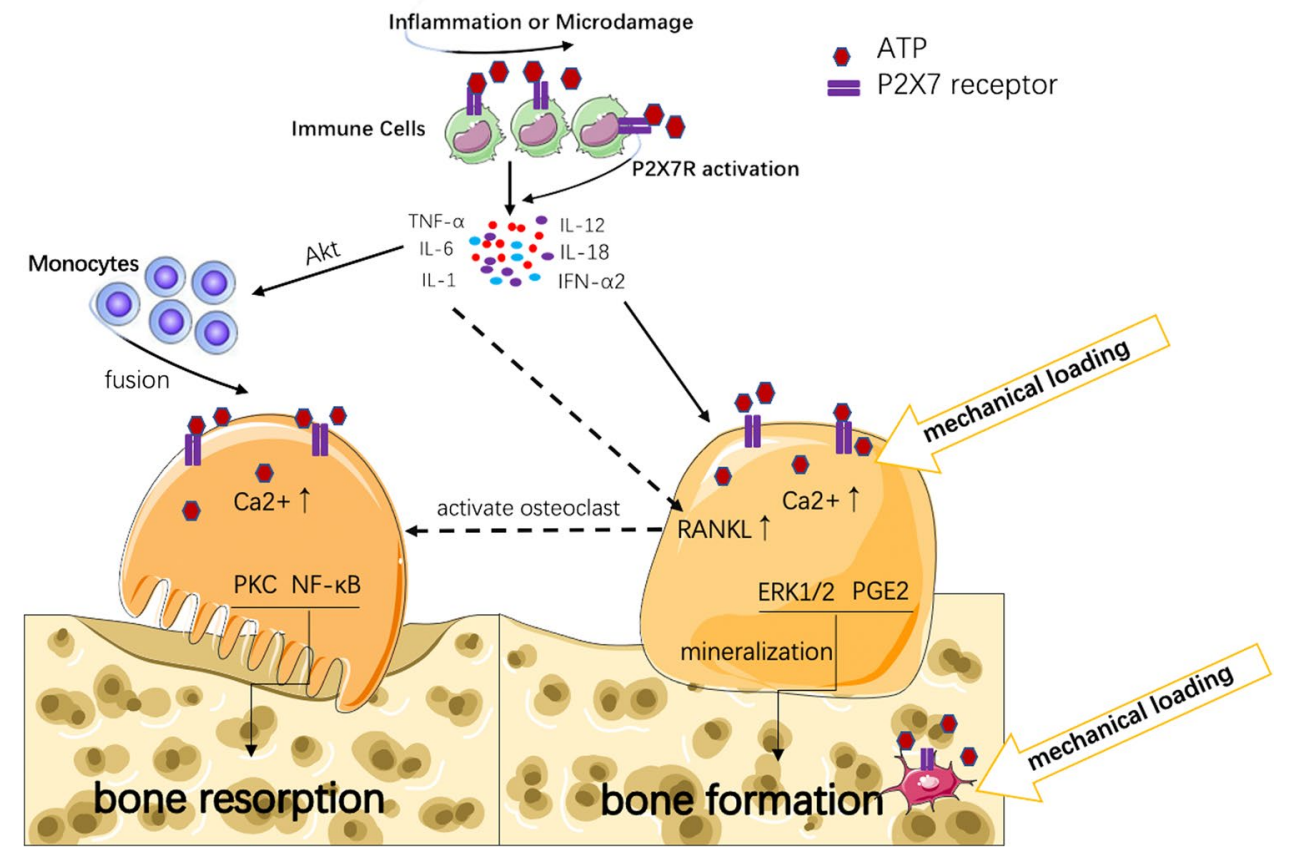

Fig. 1 The role of P2X7R in chronic inflammatory osteoporosis. Microdamage in bone tissue or inflammation causes large amounts of ATP from immune cells which activate P2X7R, and P2X7R further exacerbates the release of inflammatory cytokines from immune cells. Inflammatory cytokines (such as IL-1, IL-6, and TNF- $\alpha$ ) promote the fusion of monocytes to osteoclasts through AKT pathway,

allele have impaired ATP-induced apoptosis in osteoclasts [100-102].

Recently, it was found that P2X4R could co-expresse with P2X7R, and a heterotrophic channel could be formed between the P2X4R subunit and the P2X7R subunit. If this is true in vivo, the P2X4R subunits could theoretically replace the "defective" subunits in P2X7R to reduce the effect of genetic defects in the gene encoding P2X7R. Additionally, genes encoding P2X4R are located near and downstream of P2X7R on the same chromosome, and the polymorphism of the gene encoding P2X7R may be related to the polymorphism of the gene encoding P2X4R. So, this association could also serve as the result of gain of function or loss of function in the genes encoding P2X4R. Hence, it seems essential to investigate the association of $\mathrm{P} 2 \mathrm{X} 4$ polymorphisms with bone status and the interaction between P2X4R and P2X7R polymorphisms [74, 103].

\section{The potential therapeutic targets of P2X7R for osteoporosis}

$\mathrm{P} 2 \mathrm{X} 7 \mathrm{R}$ is increasingly recognized as a promising therapeutic target associated with inflammatory diseases, and a number of P2X7R inhibitors have been declared to be applie and enhance RANKL expression in osteoblast. RANKL promotes osteoclast formation and accelerates bone resorption. Some inflammatory cytokines (such as IL-12, IL-18, IL-33) can inhibit osteoclasts and promote osteoblast differentiation, thereby inhibiting bone loss. Mechanical stimulation can trigger the release of low-level ATP from osteoblasts or osteocytes to promote bone formation

in clinical trials [104]. Many P2X7R antagonists are also used for the treatment of osteoporosis, such as A-438079 for animal studies and A740003, Ly294002, OPG, and BBG for in vitro studies $[16,105,106]$. Unfortunately, these studies have generally shown disappointing results in terms of overall disease control [107]. Besides P2X7R antagonists, some natural pharmaceutical ingredients have been shown or speculated to have positive effects in the treatment of osteoporosis by affecting P2X7R.

Puerarin, the main component of Pueraria lobata, is an isoflavone. Puerarin has been used in the clinical treatment of cardiovascular diseases and cerebral hemorrhage in China. The results showed that the neuroprotective effects induced by Puerarin were related to the control of inflammation. Nociceptive transmission mediated by P2X3R and $\mathrm{P} 2 \mathrm{X} 2 \mathrm{R}$ in primary afferent nerve could be antagonized. Puerarin also inhibited ATP-dependent IL-1 release and maturation by suppressing the expression of $\mathrm{P} 2 \mathrm{X} 7 \mathrm{R}$ protein and mRNA. Although, this result was obtained in a burn study, since the mechanism of pain and inflammation is similar to that of inflammatory osteoporosis. So, it can be inferred that geranium could also be utilized as a new drug for the treatment of osteoporosis caused by inflammation or associated with local inflammation in the future [108]. 
Tanshinone II-A sulfonate (TIIAS), the main component of Salvia miltiorrhiza, can completely block P2X7Rmediated $\mathrm{Ca}^{2+}$ influx at low molar concentrations, thereby altering ionic currents, and can treat some P2X7R-related diseases. TIIAS are non-competitive inhibitors that interfere with ATP-induced gating when they bind to intracellular structures of the receptor. Currently, $\mathrm{Ca}^{2+}$-activated potassium channels and phosphatase 2 are two known targets of TIIAS. TIIAS can inhibit P2X7R by acting on these two targets which in turn greatly inhibit ATP-induced $\mathrm{Ca}^{2+}$ influx and Yo-Pro- 1 uptake, and counteracts the release and activation of the pro-inflammatory cytokine IL-1 in macrophages. Thus, TIIAS can attenuate the inflammatory response to some extent and inhibit inflammation-associated osteoporosis. Epimedoside is one of the main components of Epimedium, which was originally used in China to treat reproductive dysfunction. However, recent studies have shown that it is an osteogenic potential compound for bone repair and bone formation. Epimedoside has potent chondroprotective effects and may prevent bone degeneration in arthritis by preventing chondrocyte destruction. The results suggest that epimedoside can induce chondrogenesis by promoting gene expression and extracellular matrix synthesis in chondrocytes. Epimedoside could upregulate P2X7R gene expression, thereby inhibiting bone resorption, stimulating osteoblast differentiation, and increasing mineralization [109]. Besides pharmacotherapy, exercise therapy is gaining attention in the treatment of osteoporosis, and its mechanism of action may be related to involvement of P2X7R in skeletal mechanical signal transduction [110]. Previous studies have shown that mechanical force plays a crucial role in maintaining bone metabolic homeostasis and remodeling. Appropriate mechanical loading can effectively promote normal bone metabolism and maintain stability and health of bone structure and function. Osteoblasts, as the receptor cells of mechanical forces, stimulated by certain mechanical forces will release ATP extracellularly, which will increase the extracellular ATP concentration and stimulate the activation of P2X7R on the surface of osteoblasts and osteoclasts to regulate the bone metabolic process[111, 112]. It was demonstrated that fluid shear stress increases the secretion of PGE2 from osteoblasts and osteocytes in vitro, and that PGE2 has a major anabolic effect on bone formation but not $\mathrm{P} 2 \mathrm{X}^{-/-}$cells $[65,77] . \mathrm{P} 2 \mathrm{X} 7 \mathrm{R}$ mediates ERK1/2 activation via fluid shear stress [113]. Activation of P2X7R can lead to increasing bone strength through fluid shear stress-mediated ERK1/2 activation, stimulation leading to nucleotide release and thus activation of P2X7R-mediated apoptosis in osteoclasts. P2X7R is associated with the Wnt/b-catenin signaling pathway and is involved in mechanical stress-induced bone formation in anabolic responses through increased osteogenesis in load-bearing bone in response to fluid shear stress, and has a central role in the mechanical load-induced bone formation and bone scab remodeling [66, 94]. Knockdown of P2X7R results in reduced imposed growth of long bones and cranial sutures, insufficient periosteal bone formation and trabecular bone and excessive trabecular bone resorption, resulting in reduced sensitivity of the bone to mechanical loading [88, 114]. Studies of two separate populations (210 active duty Israeli soldiers and 518 UK and American elite athletes) found that the risk of stress fracture injury was associated with a loss-of-function single-nucleotide polymorphism (rs3751143, Glu496Ala) in the gene encoding the P2X7 receptor. A P2X7R gain-of-function SNP (rs1718119, Ala348Thr) was associated with decreased incidence of sexual fracture injury $[115,116]$. These evidences suggested that P2X7R mitigate osteoporosis and reduce fracture risk by promoting osteogenesis and mineralization through mechanical transduction of signals to the skeleton.

\section{Summary}

$\mathrm{P} 2 \mathrm{X7R}$, as an important signaling molecule, is both a key molecule in activating the innate immune response and central to the regulation of bone metabolism. ATP-mediated purinergic signaling is probably the key to understanding inflammation-induced bone loss. Although many studies have been conducted on P2X7R-mediated regulation of bone metabolism, the full functional role of P2X7R in osteoblasts has not been fully elucidated and has been controversial, and further elucidation of the association between P2X7R function and inflammatory bone loss is therefore needed. However, there is little doubt that P2X7R is an emerging and important therapeutic target for osteoporosis, especially for exercise therapy. Whether it is possible to improve inflammation in vivo through exercise and thus improve the outcome of osteoporosis treatment needs to be further explored.

Funding The work was kindly supported by the grants from the National Natural Science Foundation of China (11572209) and the Post-Doctor Research Project, West China Hospital, Sichuan University grant (2020HXBH158).

Data availability Data sharing is not applicable to this article as no new data were created or analyzed in this study.

\section{Declarations}

Ethical approval This article does not contain any studies with human participants or animals performed by any of the authors.

Consent to participate Not applicable.

Conflicts of interest The authors declare no competing interests. 
Open Access This article is licensed under a Creative Commons Attribution 4.0 International License, which permits use, sharing, adaptation, distribution and reproduction in any medium or format, as long as you give appropriate credit to the original author(s) and the source, provide a link to the Creative Commons licence, and indicate if changes were made. The images or other third party material in this article are included in the article's Creative Commons licence, unless indicated otherwise in a credit line to the material. If material is not included in the article's Creative Commons licence and your intended use is not permitted by statutory regulation or exceeds the permitted use, you will need to obtain permission directly from the copyright holder. To view a copy of this licence, visit http://creat ivecommons.org/licenses/by/4.0/.

\section{References}

1. Sharma D, Larriera AI, Palacio-Mancheno PE, Gatti V, Fritton JC, Bromage TG, Cardoso L, Doty SB, Fritton SP (2018) The effects of estrogen deficiency on cortical bone microporosity and mineralization. Bone 110:1-10. https://doi.org/10.1016/j.bone. 2018.01.019

2. Trémollières $F$ (2001) Les alternatives du traitement hormonal dans la prévention de l'ostéoporose post-ménopausique: les bisphosphonates [Alternatives to hormonal treatment for the prevention of postmenopausal osteoporosis: the bisphosphonates]. Gynecol Obstet Fertil. 29(11):846-52. French. https://doi.org/ 10.1016/s1297-9589(01) 00230 -2

3. Crandall CJ, Ensrud KE (2020) Osteoporosis screening in younger postmenopausal women. JAMA 323(4):367-368. https://doi.org/10.1001/jama.2019.18343

4. Schultz K, Wolf JM (2019) Emerging technologies in osteoporosis diagnosis. J Hand Surg Am 44(3):240-243. https://doi.org/ 10.1016/j.jhsa.2018.07.006

5. Chotiyarnwong P, McCloskey EV (2020) Pathogenesis of glucocorticoid-induced osteoporosisand options for treatment. Nat Rev Endocrinol 16(8):437-447. https://doi.org/10.1038/ s41574-020-0341-0

6. Raterman HG, Bultink IE, Lems WF (2020) Osteoporosis in patients with rheumatoid arthritis: an update in epidemiology, pathogenesis, and fracture prevention. Expert Opin Pharmacother 21(14):1725-1737. https://doi.org/10.1080/14656566.2020. 1787381

7. Kanazawa I, Yamaguchi T, Yamamoto M, Sugimoto T (2010) Relationship between treatments with insulin and oral hypoglycemic agents versus the presence of vertebral fractures in type 2 diabetes mellitus. J Bone Miner Metab 28(5):554-560. https:// doi.org/10.1007/s00774-010-0160-9

8. Mazzaferro S, Cianciolo G, De Pascalis A, Guglielmo C, Urena Torres PA, Bover J, Tartaglione L, Pasquali M, La Manna G (2018) Bone, inflammation and the bone marrow niche in chronic kidney disease: what do we know? Nephrol Dial Transplant 33(12):2092-2100. https://doi.org/10.1093/ ndt/gfy 115

9. Baldini V, Mastropasqua M, Francucci CM, D'Erasmo E (2005) Cardiovascular disease and osteoporosis. J Endocrinol Invest 28(10 Suppl):69-72

10. Adinolfi E, Giuliani AL, De Marchi E, Pegoraro A, Orioli E, Di Virgilio F (2018) The P2X7 receptor: a main player in inflammation. Biochem Pharmacol 151:234-244. https://doi.org/10. 1016/j.bcp.2017.12.021

11. Jørgensen NR (2019) Role of the purinergic P2X receptors in osteoclast pathophysiology. Curr Opin Pharmacol 47:97-101. https://doi.org/10.1016/j.coph.2019.02.013
12. Agrawal A, Jørgensen NR (2021) Extracellular purines and bone homeostasis. Biochem Pharmacol 187:114425. https:// doi.org/10.1016/j.bcp.2021.114425

13. Burnstock G, Arnett TR, Orriss IR (2013) Purinergic signalling in the musculoskeletal system. Purinergic Signal 9(4):541-572. https://doi.org/10.1007/s11302-013-9381-4

14. Dong Y, Chen Y, Zhang L, Tian Z, Dong S (2020) P2X7 receptor acts as an efficient drug target in regulating bone metabolism system. Biomed Pharmacother 125:110010. https://doi. org/10.1016/j.biopha.2020.110010

15. Ma Y, Ran D, Cao Y, Zhao H, Song R, Zou H, Gu J, Yuan Y, Bian J, Zhu J, Liu Z (2021) The effect of P2X7 on cadmiuminduced osteoporosis in mice. J Hazard Mater 5(405):124251. https://doi.org/10.1016/j.jhazmat.2020.124251

16. Wu W, Fu J, Gu Y, Wei Y, Ma P, Wu J (2020) JAK2/STAT3 regulates estrogen-related senescence of bone marrow stem cells. J Endocrinol 245(1):141-153. https://doi.org/10.1530/ JOE-19-0518

17. Lu J, Zhou Z, Ma J, Lu N, Lei Z, Du D, Chen A (2020) Tumour necrosis factor- $\alpha$ promotes BMHSC differentiation by increasing $\mathrm{P} 2 \mathrm{X} 7$ receptor in oestrogen-deficient osteoporosis. J Cell Mol Med 24(24):14316-14324. https://doi.org/10.1111/jcmm. 16048

18. Du D, Zhou Z, Zhu L, Hu X, Lu J, Shi C, Chen F, Chen A (2018) TNF- $\alpha$ suppresses osteogenic differentiation of MSCs by accelerating P2Y2 receptor in estrogen-deficiency induced osteoporosis. Bone 117:161-170. https://doi.org/10.1016/j.bone.2018.09.012

19. Habib P, Dreymueller D, Rösing B, Botung H, Slowik A, Zendedel A, Habib S, Hoffmann S, Beyer C (2018) Estrogen serum concentration affects blood immune cell composition and polarization in human females under controlled ovarian stimulation. J Steroid Biochem Mol Biol 178:340-347. https://doi.org/10. 1016/j.jsbmb.2018.02.005

20. Xiao W, Gong C, Liu X, Liu Y, Peng S, Luo D, Wang R, Li T, Zhao J, Xiong C, Liang S, Xu H (2019) Association of P2X7R gene with serum lipid profiles in Chinese postmenopausal women with osteoporosis. Climacteric 22(5):498-506. https:// doi.org/10.1080/13697137.2019.1604654

21. Wang H, Gong C, Liu X, Rao S, Li T, He L, Nie Y, Wang S, Zhong P, Xue Y, Wang J, Zhao J, Zhou Y, Ding L, Tu Y, Yang Y, Xiong C, Liang S, Xu H (2018) Genetic interaction of purinergic P2X7 receptor and ER- $\alpha$ polymorphisms in susceptibility to osteoporosis in Chinese postmenopausal women. J Bone Miner Metab 36(4):488-497. https://doi.org/10.1007/ s00774-017-0862-3

22. D’Amelio P, Grimaldi A, Di Bella S, Brianza SZM, Cristofaro MA, Tamone C, Giribaldi G, Ulliers D, Pescarmona GP, Isaia G (2008) Estrogen deficiency increases osteoclastogenesis upregulating T cells activity: a key mechanism in osteoporosis. Bone 43(1):92-100. https://doi.org/10.1016/j.bone.2008.02.017

23. Pacifici R, Brown C, Puscheck E, Friedrich E, Slatopolsky E, Maggio D, McCracken R, Avioli LV (1991) Effect of surgical menopause and estrogen replacement on cytokine release from human blood mononuclear cells. Proc Natl Acad Sci U S A. 88(12):5134-8. https://doi.org/10.1073/pnas.88.12.5134

24. Ryan MR, Shepherd R, Leavey JK, Gao Y, Grassi F, Schnell FJ, Qian WP, Kersh GJ, Weitzmann MN, Pacifici R (2005) An IL7-dependent rebound in thymic $\mathrm{T}$ cell output contributes to the bone loss induced by estrogen deficiency. Proc Natl Acad Sci U S A 102(46):16735-40. https://doi.org/10.1073/pnas.0505168102

25. Cenci S, Weitzmann MN, Roggia C, Namba N, Novack D, Woodring J, Pacifici R (2000) Estrogen deficiency induces bone loss by enhancing T-cell production of TNF-alpha. J Clin Invest 106(10):1229-1237. https://doi.org/10.1172/JCI11066

26. Kimble RB, Matayoshi AB, Vannice JL, Kung VT, Williams C, Pacifici R (1995) Simultaneous block of interleukin-1 and tumor 
necrosis factor is required to completely prevent bone loss in the early postovariectomy period. Endocrinology 136(7):3054-3061. https://doi.org/10.1210/endo.136.7.7789332

27. David JP (2007) Osteoimmunology: a view from the bone. Adv Immunol 95:149-165. https://doi.org/10.1016/S0065-2776(07) 95005-1

28. Kvist TM, Schwarz P, Jørgensen NR (2014) The P2X7 receptor: a key player in immune-mediated bone loss? Sci World J 2014(16):954530. https://doi.org/10.1155/2014/954530

29. Mishto M, Santoro A, Bellavista E, Bonafé M, Monti D, Franceschi C (2003) Immunoproteasomes and immunosenescence. Ageing Res Rev 2(4):419-432. https://doi.org/10.1016/s15681637(03)00030-8

30. Eikelenboom P, van Exel E, Hoozemans JJ, Veerhuis R, Rozemuller AJ, van Gool WA (2010) Neuroinflammation - an early event in both the history and pathogenesis of Alzheimer's disease. Neurodegener Dis 7(1-3):38-41. https://doi.org/10.1159/ 000283480

31. Pellanda P, Ghosh TS, O'Toole PW (2021) Understanding the impact of age-related changes in the gut microbiome on chronic diseases and the prospect of elderly-specific dietary interventions. Curr Opin Biotechnol 70:48-55. https://doi.org/10.1016/j. copbio.2020.11.001

32. Franceschi C, Garagnani P, Parini P, Giuliani C, Santoro A (2018) Inflammaging: a new immune-metabolic viewpoint for age-related diseases. Nat Rev Endocrinol 14(10):576-590. https://doi.org/10.1038/s41574-018-0059-4

33. Minciullo PL, Catalano A, Mandraffino G, Casciaro M, Crucitti A, Maltese G, Morabito N, Lasco A, Gangemi S, Basile G (2016) Inflammaging and anti-inflammaging: the role of cytokines in extreme longevity. Arch Immunol Ther Exp (Warsz) 64(2):111126. https://doi.org/10.1007/s00005-015-0377-3

34. Pietschmann P, Mechtcheriakova D, Meshcheryakova A, FögerSamwald U, Ellinger I (2016) Immunology of osteoporosis: a mini-review. Gerontology 62(2):128-137. https://doi.org/10. 1159/000431091

35. Chen K, Yang YH, Jiang SD, Jiang LS (2014) Decreased activity of osteocyte autophagy with aging may contribute to the bone loss in senile population. Histochem Cell Biol 142(3):285-295. https://doi.org/10.1007/s00418-014-1194-1

36. Pierrefite-Carle V, Santucci-Darmanin S, Breuil V, Camuzard O, Carle GF (2015) Autophagy in bone: self-eating to stay in balance. Ageing Res Rev 24(Pt B):206-217. https://doi.org/10. 1016/j.arr.2015.08.004

37. Salminen A, Kaarniranta K, Kauppinen A (2012) Inflammaging: disturbed interplay between autophagy and inflammasomes. Aging (Albany NY) 4(3):166-75. https://doi.org/10.18632/aging. 100444

38. Matsushita Y, Ono W, Ono N (2020) Skeletal stem cells for bone development and repair: diversity matters. Curr Osteoporos Rep 18(3):189-198. https://doi.org/10.1007/s11914-020-00572-9

39. Ambrosi TH, Marecic O, McArdle A, Sinha R, Gulati GS, Tong X, Wang Y, Steininger HM, Hoover MY, Koepke LS, Murphy MP, Sokol J, Seo EY, Tevlin R, Lopez M, Brewer RE, Mascharak S, Lu L, Ajanaku O, Conley SD, Seita J, Morri M, Neff NF, Sahoo D, Yang F, Weissman IL, Longaker MT, Chan CKF (2021) Aged skeletal stem cells generate an inflammatory degenerative niche. Nature 597(7875):256-262. https://doi.org/ 10.1038/s41586-021-03795-7

40. Greenblatt MB, Debnath S (2021) A stem-cell basis for skeletal ageing. Nature 597(7875):182-183. https://doi.org/10.1038/ d41586-021-02118-0

41. Wesselius A, Bours MJ, Agrawal A, Gartland A, Dagnelie PC, Schwarz P, Jorgensen NR (2011) Role of purinergic receptor polymorphisms in human bone. Front Biosci (Landmark Ed) 1(16):2572-2585. https://doi.org/10.2741/3873
42. Zhang Y, Li M, Peng X, Zhao R (2019) P2x7 receptor and inflammation-related diseases. Chin J Cell Biol 41(05):955-960

43. Gachet C, Hechler B (2020) Platelet purinergic receptors in thrombosis and inflammation. Hamostaseologie 40(2):145-152. https://doi.org/10.1055/a-1113-0711

44. Agrawal A, Gartland A (2015) P2X7 receptors: role in bone cell formation and function. J Mol Endocrinol 54(2):R75-88. https:// doi.org/10.1530/JME-14-0226

45. Macedo GC, Magnani DM, Carvalho NB, Bruna-Romero O, Gazzinelli RT, Oliveira SC (2008) Central role of MyD88dependent dendritic cell maturation and proinflammatory cytokine production to control Brucella abortus infection. $\mathbf{J}$ Immunol 180(2):1080-7. https://doi.org/10.4049/jimmunol. 180.2.1080

46. Gartland A, Hipskind RA, Gallagher JA, Bowler WB (2001) Expression of a P2X7 receptor by a subpopulation of human osteoblasts. J Bone Miner Res 16(5):846-856. https://doi.org/ 10.1359/jbmr.2001.16.5.846

47. Grol MW, Panupinthu N, Korcok J, Sims SM, Dixon SJ (2009) Expression, signaling, and function of $\mathrm{P} 2 \mathrm{X} 7$ receptors in bone. Purinergic Signal 5(2):205-221. https://doi.org/10.1007/ s11302-009-9139-1

48. Kvist TM, Syberg S, Petersen S, Ding M, Jørgensen NR, Schwarz $\mathrm{P}$ (2015) The role of the P2X7 receptor on bone loss in a mouse model of inflammation-mediated osteoporosis. Bone Rep 23(7):145-151. https://doi.org/10.1016/j.bonr.2015.09.003

49. Lemoli RM, Ferrari D, Fogli M, Rossi L, Pizzirani C, Forchap S, Chiozzi P, Vaselli D, Bertolini F, Foutz T, Aluigi M, Baccarani M, Di Virgilio F (2004) Extracellular nucleotides are potent stimulators of human hematopoietic stem cells in vitro and in vivo. Blood 104(6):1662-1670. https://doi.org/10.1182/ blood-2004-03-0834

50. Wang L, Jacobsen SE, Bengtsson A, Erlinge D (2004) P2 receptor mRNA expression profiles in human lymphocytes, monocytes and CD34+ stem and progenitor cells. BMC Immunol 3(5):16. https://doi.org/10.1186/1471-2172-5-16

51. Barbosa CM, Leon CM, Nogueira-Pedro A, Wasinsk F, Araújo RC, Miranda A, Ferreira AT, Paredes-Gamero EJ (2011) Differentiation of hematopoietic stem cell and myeloid populations by ATP is modulated by cytokines. Cell Death Dis 2(6):e165. https://doi.org/10.1038/cddis.2011.49

52. Agrawal A, Buckley KA, Bowers K, Furber M, Gallagher JA, Gartland A (2010) The effects of P2X7 receptor antagonists on the formation and function of human osteoclasts in vitro. Purinergic Signal 6(3):307-315. https://doi.org/10.1007/ s11302-010-9181-z

53. Gartland A, Buckley KA, Bowler WB, Gallagher JA (2003) Blockade of the pore-forming $\mathrm{P} 2 \mathrm{X} 7$ receptor inhibits formation of multinucleated human osteoclasts in vitro. Calcif Tissue Int 73(4):361-369. https://doi.org/10.1007/s00223-002-2098-y

54. Huang Z, Xie N, Illes P, Di Virgilio F, Ulrich H, Semyanov A, Verkhratsky A, Sperlagh B, Yu SG, Huang C, Tang Y (2021) From purines to purinergic signalling: molecular functions and human diseases. Signal Transduct Target Ther 6(1):162. https:// doi.org/10.1038/s41392-021-00553-Z

55. Hiken JF, Steinberg TH (2004) ATP downregulates P2X7 and inhibits osteoclast formation in RAW cells. Am J Physiol Cell Physiol 287(2):C403-C412. https://doi.org/10.1152/ajpcell. 00361.2003

56. Hoebertz A, Townsend-Nicholson A, Glass R, Burnstock G, Arnett TR (2000) Expression of P2 receptors in bone and cultured bone cells. Bone 27(4):503-510. https://doi.org/10.1016/ s8756-3282(00)00351-3

57. Naemsch LN, Dixon SJ, Sims SM (2001) Activity-dependent development of $\mathrm{P} 2 \mathrm{X} 7$ current and $\mathrm{Ca} 2+$ entry in rabbit 
osteoclasts. J Biol Chem 276(42):39107-14. https://doi.org/10. 1074/jbc.M105881200

58. Jørgensen NR, Henriksen Z, Sørensen OH, Eriksen EF, Civitelli $R$, Steinberg TH (2002) Intercellular calcium signaling occurs between human osteoblasts and osteoclasts and requires activation of osteoclast P2X7 receptors. J Biol Chem 277(9):7574-80. https://doi.org/10.1074/jbc.M104608200

59. Brandao-Burch A, Key ML, Patel JJ, Arnett TR, Orriss IR (2012) The P2X7 receptor is an important regulator of extracellular ATP levels. Front Endocrinol (Lausanne) 19(3):41. https://doi.org/10. 3389/fendo.2012.00041

60. Morrison MS, Turin L, King BF, Burnstock G, Arnett TR (1998) ATP is a potent stimulator of the activation and formation of rodent osteoclasts. J Physiol 511(2):495-500. https://doi.org/10. 1111/j.1469-7793.1998.495bh.x

61. Surprenant A, Rassendren F, Kawashima E, North RA, Buell G (1996) The cytolytic P2Z receptor for extracellular ATP identified as a P2X receptor (P2X7). Science 272(5262):735-8. https:// doi.org/10.1126/science.272.5262.735

62. Biver G, Wang N, Gartland A, Orriss I, Arnett TR, Boeynaems JM, Robaye B (2013) Role of the P2Y13 receptor in the differentiation of bone marrow stromal cells into osteoblasts and adipocytes. Stem Cells 31(12):2747-2758. https://doi.org/10. 1002/stem.1411

63. Zippel N, Limbach CA, Ratajski N, Urban C, Luparello C, Pansky A, Kassack MU, Tobiasch E (2012) Purinergic receptors influence the differentiation of human mesenchymal stem cells. Stem Cells Dev 21(6):884-900. https://doi.org/10.1089/scd. 2010.0576

64. Sun D, Junger WG, Yuan C, Zhang W, Bao Y, Qin D, Wang C, Tan L, Qi B, Zhu D, Zhang X, Yu T (2013) Shockwaves induce osteogenic differentiation of human mesenchymal stem cells through ATP release and activation of $\mathrm{P} 2 \mathrm{X} 7$ receptors. Stem Cells 31(6):1170-1180. https://doi.org/10.1002/stem.1356

65. Noronha-Matos JB, Coimbra J, Sá-e-Sousa A, Rocha R, Marinhas J, Freitas R, Guerra-Gomes S, Ferreirinha F, Costa MA, Correia-de-Sá P (2014) P2X7-induced zeiosis promotes osteogenic differentiation and mineralization of postmenopausal bone marrow-derived mesenchymal stem cells. FASEB J 28(12):5208-5222. https://doi.org/10.1096/fj.14-257923

66. Orriss IR, Knight GE, Ranasinghe S, Burnstock G, Arnett TR (2006) Osteoblast responses to nucleotides increase during differentiation. Bone 39(2):300-309. https://doi.org/10.1016/j.bone. 2006.02.063

67. Nakamura E, Uezono Y, Narusawa K, Shibuya I, Oishi Y, Tanaka M, Yanagihara N, Nakamura T, Izumi F (2000) ATP activates DNA synthesis by acting on P2X receptors in human osteoblastlike MG-63 cells. Am J Physiol Cell Physiol 279(2):C510-C519. https://doi.org/10.1152/ajpcell.2000.279.2.C510

68. Panupinthu N, Rogers JT, Zhao L, Solano-Flores LP, Possmayer F, Sims SM, Dixon SJ (2008) P2X7 receptors on osteoblasts couple to production of lysophosphatidic acid: a signaling axis promoting osteogenesis. J Cell Biol 181(5):859-71. https://doi. org/10.1083/jcb.200708037

69. Ke HZ, Qi H, Weidema AF, Zhang Q, Panupinthu N, Crawford DT, Grasser WA, Paralkar VM, Li M, Audoly LP, Gabel CA, Jee WS, Dixon SJ, Sims SM, Thompson DD (2003) Deletion of the P2X7 nucleotide receptor reveals its regulatory roles in bone formation and resorption. Mol Endocrinol 17(7):13561367. https://doi.org/10.1210/me.2003-0021

70. Giuliani AL, Colognesi D, Ricco T, Roncato C, Capece M, Amoroso F, Wang QG, De Marchi E, Gartland A, Di Virgilio F, Adinolfi E (2014) Trophic activity of human P2X7 receptor isoforms A and B in osteosarcoma. PLoS One 9(9):e107224. https://doi.org/10.1371/journal.pone.0107224
71. Grol MW, Zelner I, Dixon SJ (2012) P2X7-mediated calcium influx triggers a sustained, PI3K-dependent increase in metabolic acid production by osteoblast-like cells. Am J Physiol Endocrinol Metab 302(5):E561-75. https://doi.org/10.1152/ ajpendo.00209.2011

72. Panupinthu N, Zhao L, Possmayer F, Ke HZ, Sims SM, Dixon SJ (2007) P2X7 nucleotide receptors mediate blebbing in osteoblasts through a pathway in Panupinthu N, Zhao L olving lysophosphatidic acid. J Biol Chem 282(5):3403-12. https:// doi.org/10.1074/jbc.M605620200

73. Orriss IR, Key ML, Hajjawi MO, Arnett TR (2013) Extracellular ATP released by osteoblasts is a key local inhibitor of bone mineralisation. PLoS One 8(7):e69057. https://doi.org/ 10.1371/journal.pone.0069057

74. Liu D, Genetos DC, Shao Y, Geist DJ, Li J, Ke HZ, Turner CH, Duncan RL (2008) Activation of extracellular-signal regulated kinase $(\mathrm{ERK} 1 / 2)$ by fluid shear is $\mathrm{Ca}(2+)$ - and ATP-dependent in MC3T3-E1 osteoblasts. Bone 42(4):644-652. https://doi. org/10.1016/j.bone.2007.09.058

75. Orriss IR, Utting JC, Brandao-Burch A, Colston K, Grubb BR, Burnstock G, Arnett TR (2007) Extracellular nucleotides block bone mineralization in vitro: evidence for dual inhibitory mechanisms involving both $\mathrm{P} 2 \mathrm{Y} 2$ receptors and pyrophosphate. Endocrinology 148(9):4208-4216. https://doi.org/10. 1210/en.2007-0066

76. Genetos DC, Geist DJ, Liu D, Donahue HJ, Duncan RL (2005) Fluid shear-induced ATP secretion mediates prostaglandin release in MC3T3-E1 osteoblasts. J Bone Miner Res 20(1):4149. https://doi.org/10.1359/JBMR.041009

77. Jørgensen NR, Husted LB, Skarratt KK, Stokes L, Tofteng CL, Kvist T, Jensen JE, Eiken P, Brixen K, Fuller S, Clifton-Bligh R, Gartland A, Schwarz P, Langdahl BL, Wiley JS (2012) Single-nucleotide polymorphisms in the $\mathrm{P} 2 \mathrm{X} 7$ receptor gene are associated with post-menopausal bone loss and vertebral fractures. Eur J Hum Genet 20(6):675-681. https://doi.org/10. 1038/ejhg.2011.253

78. Zhang B, Hou R, Zou Z, Luo T, Zhang Y, Wang L, Wang B (2018) Mechanically induced autophagy is associated with ATP metabolism and cellular viability in osteocytes in vitro. Redox Biol 14:492-498. https://doi.org/10.1016/j.redox.2017. 10.021

79. Orriss IR, Key ML, Brandao-Burch A, Patel JJ, Burnstock G, Arnett TR (2012) The regulation of osteoblast function and bone mineralisation by extracellular nucleotides: the role of p2x receptors. Bone 51(3):389-400. https://doi.org/10.1016/j. bone.2012.06.013

80. Karkache IY, Damodaran JR, Molstad DHH, Bradley EW (2021) Serine/threonine phosphatases in osteoclastogenesis and bone resorption. Gene 1(771):145362. https://doi.org/10. 1016/j.gene.2020.145362

81. Li J, Liu D, Ke HZ, Duncan RL, Turner CH (2005) The P2X7 nucleotide receptor mediates skeletal mechanotransduction. J Biol Chem. 280(52):42952-9. https://doi.org/10.1074/jbc. M506415200

82. Li M, Thompson DD, Paralkar VM (2007) Prostaglandin E(2) receptors in bone formation. Int Orthop 31(6):767-772. https:// doi.org/10.1007/s00264-007-0406-x

83. Yoshida K, Oida H, Kobayashi T, Maruyama T, Tanaka M, Katayama T, Yamaguchi K, Segi E, Tsuboyama T, Matsushita M, Ito K, Ito Y, Sugimoto Y, Ushikubi F, Ohuchida S, Kondo K, Nakamura T, Narumiya S (2002) Stimulation of bone formation and prevention of bone loss by prostaglandin E EP4 receptor activation. Proc Natl Acad Sci U S A 99(7):4580-5. https://doi. org/10.1073/pnas.062053399

84. Cherian PP, Siller-Jackson AJ, Gu S, Wang X, Bonewald LF, Sprague E, Jiang JX (2005) Mechanical strain opens connexin 43 
hemichannels in osteocytes: a novel mechanism for the release of prostaglandin. Mol Biol Cell 16(7):3100-3106. https://doi.org/ 10.1091/mbc.e04-10-0912

85. Gratal P, Lamuedra A, Medina JP, Bermejo-Álvarez I, Largo R, Herrero-Beaumont G, Mediero A (2020) Purinergic system signaling in metainflammation-associated osteoarthritis. Front Med (Lausanne) 28(7):506. https://doi.org/10.3389/fmed.2020. 00506

86. Ferrari D, Pizzirani C, Adinolfi E, Lemoli RM, Curti A, Idzko M, Panther E, Di Virgilio F (2006) The P2X7 receptor: a key player in IL-1 processing and release. J Immunol. 176(7):387783. https://doi.org/10.4049/jimmunol.176.7.3877. Erratum in: J Immunol. 2007 Dec 15;179(12):8569.

87. Di Virgilio F, Dal Ben D, Sarti AC, Giuliani AL, Falzoni S (2017) The P2X7 receptor in infection and inflammation. Immunity 47(1):15-31. https://doi.org/10.1016/j.immuni.2017.06.020

88. Sun Q, Scott MJ (2016) Caspase-1 as a multifunctional inflammatory mediator: noncytokine maturation roles. J Leukoc Biol 100(5):961-967. https://doi.org/10.1189/jlb.3MR0516-224R

89. Solle M, Labasi J, Perregaux DG, Stam E, Petrushova N, Koller BH, Griffiths RJ, Gabel CA (2001) Altered cytokine production in mice lacking P2X(7) receptors. J Biol Chem 276(1):125-32. https://doi.org/10.1074/jbc.M006781200

90. Tedder TF, Crain MJ, Kubagawa H, Clement LT, Cooper MD (1985) Evaluation of lymphocyte differentiation in primary and secondary immunodeficiency diseases. J Immunol 135(3):1786-1791

91. Matsumoto T, Endo I (2021) RANKL as a target for the treatment of osteoporosis. J Bone Miner Metab 39(1):91-105. https://doi. org/10.1007/s00774-020-01153-7

92. Ma Y, Zhao H, Chile C, Wang C, Zheng J, Song R, Zou H, Gu J, YanYuan Bian J, Liu Z (2019) The effect of P2X7R-mediated $\mathrm{Ca} 2+$ signaling in OPG-induced osteoclasts adhesive structure damage. Exp Cell Res 383(2):111555. https://doi.org/10.1016/j. yexcr.2019.111555

93. De Marchi E, Orioli E, Dal Ben D, Adinolfi E (2016) P2X7 receptor as a therapeutic target. Adv Protein Chem Struct Biol 104:39-79. https://doi.org/10.1016/bs.apcsb.2015.11.004

94. Zhou L, Luo L, Qi X, Li X, Gorodeski GI (2009) Regulation of P2X(7) gene transcription. Purinergic Signal 5(3):409-426. https://doi.org/10.1007/s11302-009-9167-x

95. Zeng D, Yao P, Zhao H (2019) P2X7, a critical regulator and potential target for bone and joint diseases. J Cell Physiol 234(3):2095-2103. https://doi.org/10.1002/jcp.27544

96. Husted LB, Harsløf T, Stenkjær L, Carstens M, Jørgensen NR, Langdahl BL (2013) Functional polymorphisms in the P2X7 receptor gene are associated with osteoporosis. Osteoporos Int 24(3):949-959. https://doi.org/10.1007/s00198-012-2035-5

97. Gartland A, Skarratt KK, Hocking LJ, Parsons C, Stokes L, Jørgensen NR, Fraser WD, Reid DM, Gallagher JA, Wiley JS (2012) Polymorphisms in the $\mathrm{P} 2 \mathrm{X} 7$ receptor gene are associated with low lumbar spine bone mineral density and accelerated bone loss in post-menopausal women. Eur J Hum Genet 20(5):559-564. https://doi.org/10.1038/ejhg.2011.245

98. Liu X, Rao S, Gong C, Li T, Ding L, Wang S, Zhong P, Wang J, Zhao J, Zhou Y, Xiong C, Tu Y, Liang S, Xu H (2018) Purinergic $\mathrm{P} 2 \mathrm{X} 7$ receptor functional genetic polymorphisms are associated with the susceptibility to obesity in Chinese postmenopausal women. Menopause 25(3):329-335. https://doi.org/10.1097/ GME.0000000000000991

99. Wesselius A, Bours MJ, Henriksen Z, Syberg S, Petersen S, Schwarz P, Jørgensen NR, van Helden S, Dagnelie PC (2013) Association of $\mathrm{P} 2 \mathrm{X} 7$ receptor polymorphisms with bone mineral density and osteoporosis risk in a cohort of Dutch fracture patients. Osteoporos Int 24(4):1235-1246. https://doi.org/10. 1007/s00198-012-2059-x
100. Shemon AN, Sluyter R, Fernando SL, Clarke AL, Dao-Ung LP, Skarratt KK, Saunders BM, Tan KS, Gu BJ, Fuller SJ, Britton WJ, Petrou S, Wiley JS (2006) A Thr357 to Ser polymorphism in homozygous and compound heterozygous subjects causes absent or reduced P2X7 function and impairs ATP-induced mycobacterial killing by macrophages. J Biol Chem 281(4):2079-86. https://doi.org/10.1074/jbc.M507816200

101. Gu BJ, Zhang W, Worthington RA, Sluyter R, Dao-Ung P, Petrou S, Barden JA, Wiley JS (2001) A Glu-496 to Ala polymorphism leads to loss of function of the human P2X7 receptor. J Biol Chem 276(14):11135-42. https://doi.org/10.1074/jbc.M0103 53200

102. Varley I, Hughes DC, Greeves JP, Fraser WD, Sale C (2018) SNPs in the vicinity of P2X7R, RANK/RANKL/OPG and Wnt signalling pathways and their association with bone phenotypes in academy footballers. Bone 108:179-185. https://doi.org/10. 1016/j.bone.2018.01.007

103. Guo C, Masin M, Qureshi OS, Murrell-Lagnado RD (2007) Evidence for functional P2X4/P2X7 heteromeric receptors. Mol Pharmacol 72(6):1447-1456. https://doi.org/10.1124/mol.107. 035980

104. Illes P, Müller CE, Jacobson KA, Grutter T, Nicke A, Fountain SJ, Kennedy C, Schmalzing G, Jarvis MF, Stojilkovic SS, King BF, Di Virgilio F (2021) Update of P2X receptor properties and their pharmacology: IUPHAR Review 30. Br J Pharmacol 178(3):489-514. https://doi.org/10.1111/bph.15299

105. von Muecke-Heim IA, Ries C, Urbina L, Deussing JM (2021) P2X7R antagonists in chronic stress-based depression models: a review. Eur Arch Psychiatry Clin Neurosci 271(7):1343-1358. https://doi.org/10.1007/s00406-021-01306-3

106. Xu XY, He XT, Wang J, Li X, Xia Y, Tan YZ, Chen FM (2019) Role of the P2X7 receptor in inflammation-mediated changes in the osteogenesis of periodontal ligament stem cells. Cell Death Dis 10(1):20. https://doi.org/10.1038/s41419-018-1253-y

107. Pournara DT, Durner A, Kritsi E, Papakostas A, Zoumpoulakis P, Nicke A, Koufaki M (2020) Design, Synthesis, and in vitro evaluation of P2X7 antagonists. ChemMedChem 15(24):2530 2543. https://doi.org/10.1002/cmdc.202000303

108. Zhang J, Li X, Gao Y, Guo G, Xu C, Li G, Liu S, Huang A, Tu G, Peng H, Qiu S, Fan B, Zhu Q, Yu S, Zheng C, Liang S (2013) Effects of puerarin on the inflammatory role of burnrelated procedural pain mediated by $\mathrm{P} 2 \mathrm{X}(7)$ receptors. Burns 39(4):610-618. https://doi.org/10.1016/j.burns.2012.08.013

109. Dai S, Shi X, Qin R, Zhang X, Xu F, Yang H (2021) Sodium Tanshinone IIA Sulfonate Ameliorates injury-induced oxidative stress and intervertebral disc degeneration in rats by inhibiting p38 MAPK signaling pathway. Oxid Med Cell Longev. 5556122. Published 2021 May 25. https://doi.org/10.1155/2021/5556122

110. Chen Y, Dou C, Yi J, Tang R, Yu T, Zhou L, Luo W, Liang M, Yin X, Li J, Kang F, Zhao Y, Dong S (2018) Inhibitory effect of vanillin on RANKL-induced osteoclast formation and function through activating mitochondrial-dependent apoptosis signaling pathway. Life Sci 1(208):305-314. https://doi.org/10.1016/j.lfs. 2018.07.048

111. Orriss I, Syberg S, Wang N, Robaye B, Gartland A, Jorgensen N, Arnett T, Boeynaems JM (2011) Bone phenotypes of P2 receptor knockout mice. Front Biosci (Schol Ed) 1(3):1038-1046. https:// doi.org/10.2741/208

112. Knapik DM, Perera P, Nam J, Blazek AD, Rath B, Leblebicioglu B, Das H, Wu LC, Hewett TE, Agarwal SK Jr, Robling AG, Flanigan DC, Lee BS, Agarwal S (2014) Mechanosignaling in bone health, trauma and inflammation. Antioxid Redox Signal 20(6):970-85. https://doi.org/10.1089/ars.2013.5467

113. Bratengeier C, Bakker AD, Fahlgren A (2019) Mechanical loading releases osteoclastogenesis-modulating factors through stimulation of the $\mathrm{P} 2 \mathrm{X} 7$ receptor in hematopoietic progenitor cells. 
J Cell Physiol 234(8):13057-13067. https://doi.org/10.1002/jcp. 27976

114. Okumura H, Shiba D, Kubo T, Yokoyama T (2008) P2X7 receptor as sensitive flow sensor for ERK activation in osteoblasts. Biochem Biophys Res Commun. 372(3):486-90. https://doi.org/ 10.1016/j.bbrc.2008.05.066

115. Li J, Meyer R, Duncan RL, Turner CH (2009) P2X7 nucleotide receptor plays an important role in callus remodeling during fracture repair. Calcif Tissue Int 84(5):405-412. https://doi.org/10. 1007/s00223-009-9237-7
116. Varley I, Greeves JP, Sale C, Friedman E, Moran DS, Yanovich R, Wilson PJ, Gartland A, Hughes DC, Stellingwerff T, Ranson C, Fraser WD, Gallagher JA (2016) Functional polymorphisms in the P2X7 receptor gene are associated with stress fracture injury. Purinergic Signal 12(1):103-113. https://doi.org/10.1007/ s11302-016-9495-6

Publisher's note Springer Nature remains neutral with regard to jurisdictional claims in published maps and institutional affiliations. 